\title{
The Impact of Reverse Logistics on Operational Performance
}

\author{
Zhang Yu ${ }^{1, *}$, Ma Tianshan ${ }^{1}$, Muhammad Faheem Ud Din ${ }^{2}$ \\ ${ }^{1}$ School of Economics and Management, Chang'an University, Xi'an, China \\ ${ }^{2}$ Department of Literature and Linguistics, National University of Modern Languages, Islamabad, Pakistan
}

Email address:

zhangyu19@foxmail.com (Zhang Yu),ufaheem198@gmail.com (M. F. Ud Din)

${ }^{*}$ Corresponding author

\section{To cite this article:}

Zhang Yu, Ma Tianshan, Muhammad Faheem Ud Din. The Impact of Reverse Logistics on Operational Performance. American Journal of Mechanical and Industrial Engineering. Vol. 3, No. 5, 2018, pp. 99-104. doi: 10.11648/j.ajmie.20180305.14

Received: October 28, 2018; Accepted: November 13, 2018; Published: December 11, 2018

\begin{abstract}
Logistics management is an integrated part of supply chain management. Reverse logistics is for all operations related to the reuse of products and materials. It is "the process of moving goods from their typical final destination for the purpose of recycling, reuse, capturing value, or proper disposal. Remanufacturing and refurbishing activities also may be included in the definition of reverse logistics." Growing green concerns and advancement of green supply chain management concepts and practices make it all the more relevant. The number of publications on the topic of reverse logistics has increased significantly over the past two decades. This research paper investigates the relationship between reverse logistics operation, environmental performance, and competitive advantage, financial and operational performance of pharmaceutical firms located in India. This research paper has been adopted simultaneous regression method to test hypothesis. The results indicate that all endogenous (operational, environmental and financial performance) except competitive advantage are positively and significantly correlated with reverse logistics operations, while competitive advantages and reverse logistics operations have insignificant relationship. In addition, due to adoption of reverse logistics, firms may increase their overall performance and increase the efficiency of manufacturing processes due to elimination of waste. Furthermore, implementing reverse logistics operations, more opportunities to firms to improve their products' quality and reduce their end-to-end supply chain cost will take place.
\end{abstract}

Keywords: Reverse Logistics, Operational Performance, Environmental Performance, Competitive Advantage, Financial Performance

\section{Introduction}

In last couple of years, the concept of reverse logistics were booming and a number of firms started to consider and adopt reverse logistics function in their supply chain as a mandatory function. Definitely, reverse logistics function is mainly based on collecting used, broken and expired products from customers for remanufacturing, recycling, and refilling etc. The best example for understanding reverse logistics concept is beverage firms such as COCA Cola or PEPSI, they distribute their beverages to distributors or retailers and after couple of days, firms again distribute new filled bottles of beverages and collecte empty bottles for refilling. Usually firms give incentive to consumers for "returning empty bottles" and also give some percentage to retailers for their efforts to motivate consumers to return empty bottles. The primary goal of reverse logistics is to reduce harmful effects on environmental sustainability and also increase efficiency of supply chain with reduction of costs. Green et al., [1] highlighted that the primary objective of reverse logistics cannot be to make profits without proper integration between end-to-end supply chain members (See Figure 1). Tsoulfas and Pappis [2] onducted a research to explore the advantages of reverse logistics. The findings show that reverse logistics is not only reducing harmful effects on environment but also enhancing financial performance and operational performance of firms. In similar line, Thierry et al., [3] and Brito et al., [4] had been reported that reverse logistics have its reasons because of several 
advantages. The most significant reasons are the following:

1. Economic: decreasing the use of components and raw materials, creating more added value for end-to-use

products, and reducing disposal costs), improving customer relations and demonstration of environmentally responsible behavior.

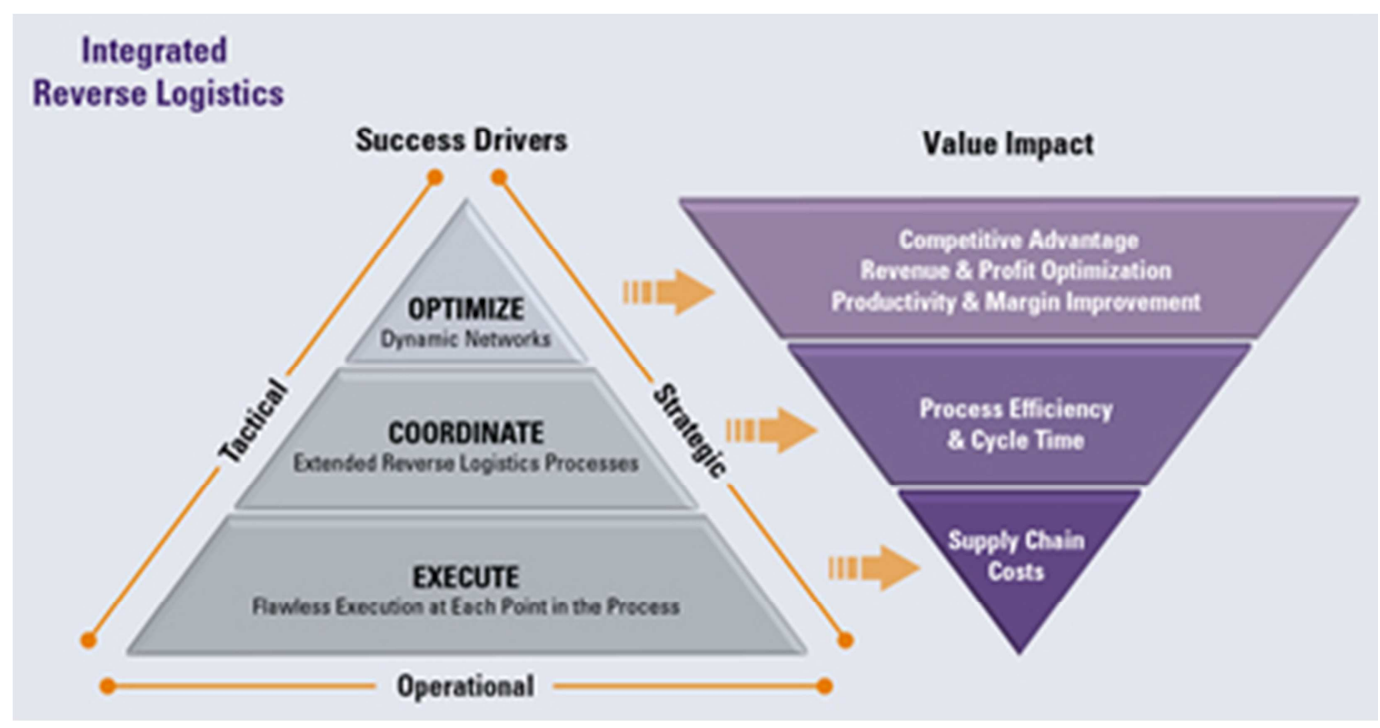

Figure 1. Integrated Reverse Logistics.

2. Legal: in many European and Western countries, companies are held accountable for the recovery or correction on disposal of waste generated by products they manufacture.

3. Social: the increased social awareness in need to protect the environment has led to increasing demands for environmentally responsible behavior by firms.

For another side, there is also some problems and challenges faced by firms. Subramanian and Subramanyam, [5]; Agrawal et al., [6] found some marketing challenges in the remanufactured and recycled products for example:

1. The willingness to pay (WTP) for remanufactured products: Michaud and Llerena, [7] used experimental auctions to describe consumers' WTP for remanufactured products, looking for evidence that consumers tend to value the remanufactured product less than the original one, and are not willing to pay a premium for the remanufactured product.

2. Cannibalization: Atasu et al., [8] showed that remanufacturing does not always cannibalize new product sales, and if it does, the additional profits of remanufacturing can outweigh the cannibalization costs; for this same issue.

3. Competition: this is another issue faced by firms, because a firm who sell remanufactured products is often unable to compete with a firm who only sell original products.

In this article, an introduction to the reverse logistics concept has been presented. The main idea and contribution of this research is to explore the answer of the following questions:

Q.1. Does reverse logistics reduce end-to-end supply chain costs and increase financial and environmental performance?

Q.2. Does reverse logistics really build a competitive advantage for the firms in terms of customer satisfaction, trust and social acceptance?
Q.3. Does reverse logistics increase the efficiency of supply chain and logistics operations due to waste reduction?

\section{Literature Review and Hypothesis Development}

Logistics management is an integrated part of supply chain management [9]. According to the Lin, [10] and Stank et al. [11] integrating logistics processes of all supply chain partners are to better serve the needs of ultimate customers. The Council of Supply Chain Management Professionals [12] defined logistics management as "that part of supply chain management that plans, implements and controls the efficient, effective forward and reverse flow of goods. Rodrigues et al. [11] recognize that in supply chain, a big portion of cost is logistics operation and it will increase in global logistics context. Rabinovich and Knemeyer [12] conducted a research on advantages and challenges involved in reverse logistics. The results showed that firms may improve their financial performance in terms of cost cutting and reduction of materials, recycling and remanufacturing procedure. In addition, reverse logistics also helps firms to improve environmental performance and provide opportunity to build competitive advantage in the market. Lai and Cheng [13] discuss the importance of a supply chain focus on the part of transport logistics service providers as they function to link suppliers, manufacturers, sellers, and customers throughout the supply chain. They argue that transport logistics service providers must focus on supply chain performance in addition to organizational performance.

Chopra and Meindl, [14] highlighted that reverse logistics reduces the cost of supply chain and increase the efficiency of processes. Meredith and Shafer, [15] explained that recycling and remanufacturing techniques not only protect 
environmental sustainability but also improve financial performance of supply chain and increase customers satisfaction and trust on firms' products. The logistics performance construct reflects the organization's performance as it relates to its ability to deliver goods and services in the precise quantities and at precise time required by customers. Bowersox et al. [16] incorporated performance metrics such as customer satisfaction, delivery speed, delivery dependability, and delivery flexibility. Marketing performance reflects the organization's ability to increase sales and expand market share as compared to its competition $(17 ; 18)$.

According to the numerous researchers, reverse logistics is a small part of green supply chain management, because green supply chain management bottom line is to enhance environmental sustainability without reducing economic growth of firms. But the ideology of green supply chain is far greater than reverse logistics. If firms work on reverse logistics so partially they may also work on green practices and/or green manufacturing. Khan and Dong, [19] Green manufacturing includes applying the green resources in industry, which can in the long run lead to competitive advantage by increasing efficiency through increasing production quality and output at optimum cost. Green manufacturing is associated with manufacturing production practices which use more environmentally-friendly resources and provide maximum output with little or no waste or pollution during production. Claycomb et al., [20] and Green et al., [21] Green manufacturing can lead to use reduction of raw materials, reduction of energy consumption, fewer manufacturing steps, and lower environmental and occupational safety expenses, along with an improved corporate image. Vokurka and Lummus [22] specified the primary objective of reverse logistics as adding value for customers and also reducing supply chain costs. The added value should be reflected in the cost, quality, flexibility, and delivery components of supply chain performance.

Oliver and Delbridge [23] described that reverse logistics functions enhance customers' loyalty and provide opportunity to firms to build strong relationship with customers. On the other hand, Carter and Narasimhan, [24] reverse logistics creates financial burden on supply chain performance and also reduces the quality of products. Wisner [25] surveyed US and European manufacturing and service organizations and structurally assessed a model that incorporated supplier management and customer relationship strategies as antecedents to supply chain management strategy and firm performance as a consequence. Additional empirical evidence was provided by Armistead and Mapes [26], who collected data from 38 UK manufacturing organizations. They measured supply chain integration and perceptions of manufacturing performance and found them be highly and positively correlated.

Green et al. [27] surveyed sales managers for manufacturing firms and found a positive link between reverser logistics, environmental and financial performance. Khan and Dong, [19] conducted research to investigate the linkage between reverse logistics and competitive advantage. The findings showed that reverse logistics is significantly and positively correlated with organizational performance and also provides opportunity to firms to build competitive advantage through social services, reliability and strong relationship with customers. On the basis of above cited research papers, we have developed the following hypothesis:

H1: Reverse logistics improves financial performance of the firms.

$\mathrm{H} 2$ : Reverse logistics protects environmental sustainability and increases environmental performance of firms

H3: Reverse logistics provides opportunity to build competitive advantage in the market

H4: Reverse logistics increases operational efficiency due to waste reduction.

\section{Methodology}

This research paper has adopted linear regression technique to test hypothesis. First of all, we developed pre-test questionnaire for pilot study and after consultation with seniors' industry experts, we developed the final questionnaire with improvement. The questionnaire mainly covered five portion including reverse logistics, operational performance, competitive advantage, financial and environmental performance. The data were taken from supply chain specialist of pharmaceutical companies located in Mumbai, India during January to April 2017. Figure 2 draws the research model.

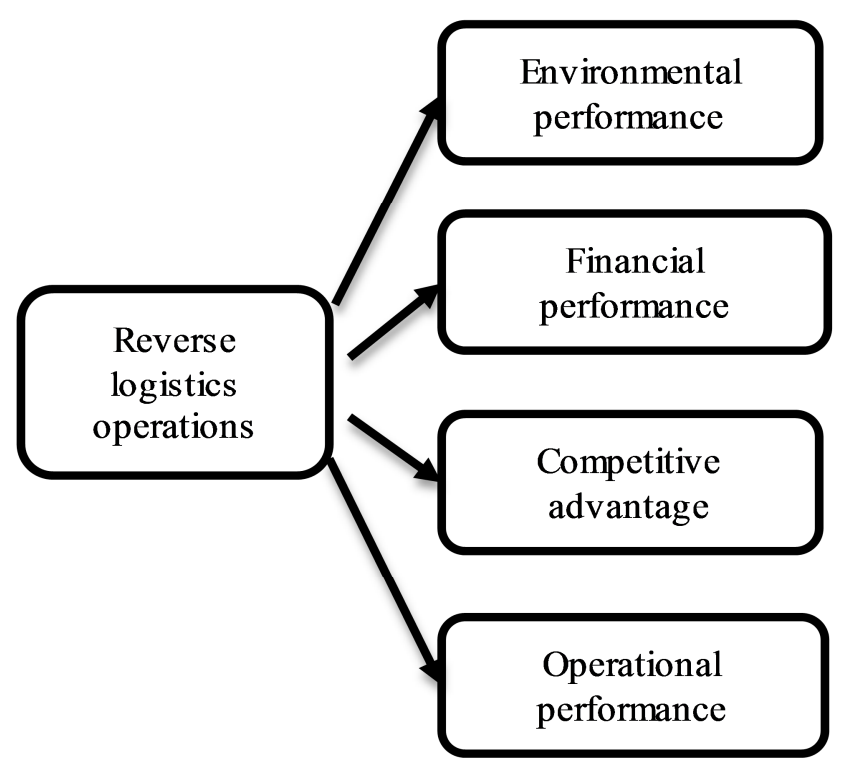

Figure 2. Research model.

A total of 147 filled questionnaires were received, 26 were identified as not suitable and useable. The data from 121 firms detailed were included in the dataset for further analysis. The primary goal is to measure the theorized model. Table 1 indicates the demographic profile of firms. 
Table 1. Respondents profile.

\begin{tabular}{ll}
\hline Demographics & Number of respondents \\
\hline Job title & 99 \\
Supply chain officers & 22 \\
Supply chain managers & \\
Age of firm & 9 \\
Less than 5 years & 16 \\
5 to 10 years & 26 \\
11 to 15 years & 57 \\
16 to 20 years & 13 \\
More than 20 years & \\
Number of employees & 11 \\
Less than 50 workers & 31 \\
50 to 100 workers & 48 \\
101 to 160 workers & 23 \\
161 to 250 workers & 8 \\
More than 250 workers & \\
\hline
\end{tabular}

\section{Results and Discussion}

The research performs reliability, descriptive statistics, and correlational matrix before going towards adopting linear multiple regression method. The table 2 shows the descriptive statistics and correlation between endogenous and exogenous variables.

Table 2. Descriptive Statistics and Correlational Matrix.

\begin{tabular}{llllllll}
\hline & Mean & Std. Dev. & $\mathbf{1}$ & $\mathbf{2}$ & $\mathbf{3}$ & $\mathbf{4}$ & $\mathbf{5}$ \\
\hline 1 & 1.68 & 0.54 & 1 & & & & \\
2 & 2.14 & 0.72 & $0.361^{* *}$ & 1 & & & \\
3 & 2.89 & 1.04 & $0.141^{* *}$ & $0.304^{* *}$ & 1 & & \\
4 & 2.18 & 0.91 & 0.139 & $0.441^{*}$ & 0.324 & 1 & \\
5 & 1.74 & 0.65 & $0.471^{*}$ & $0.431^{* *}$ & $0.211^{* *}$ & 0.251 & 1 \\
\hline
\end{tabular}

Note: ${ }^{*}$ p.05 (2-tailed); ${ }^{*}$ p $<.01$ (2-tailed)

1 indicate reverse logistics operation; 2 shows environmental performance; 3 shows financial performance; 4 display operational performance and 5 indicate competitive advantage.

Table 3 draws the simultaneous regression results. The findings show that revers logistics really has positive and significant relationship with environmental, financial and operational performance except competitive advantage. The results indicate that competitive advantage and reverse logistics operation has insignificant relationship.

Table 3. Results of Hypothesis.

\begin{tabular}{lllllll}
\hline Hyp. & Predictors & SE & B & VIF & t-stat & Sig \\
\hline & (Constant) & .121 & .514 & & 4.252 & 0.000 \\
H1 & Environmental & .042 & .182 & 1.311 & 2.781 & $0.000^{* *}$ \\
H2 & Financial & .035 & .115 & 1.444 & 5.112 & $0.000^{* *}$ \\
H3 & Operational & .038 & .121 & 1.541 & 6.145 & $0.003^{*}$ \\
H4 & Competitive & .035 & .213 & 1.129 & 0.415 & 0.312 \\
\hline
\end{tabular}

$\mathrm{F}=37.22 ;$ Adj $\mathrm{R} 2=42.4 ; * \mathrm{P}<.05 ; * * \mathrm{P}<.001$

In our results, environmental performance can be increased by $18.2 \%$ through adoption of reverse logistics operation. The results also are supported by Guide and Wassenhove [28]. They conducted their study to investigate the association between reverse logistics and environmental performance in the context of European countries. The finding shows that due to adoption of reverse logistics environmental performance significantly increases. Because the bottom line of reverse logistics is to reduce the harmful effects on environment and use recycling and remanufacturing techniques, which not only reduce the solid waste but also increase the efficiency of processes. Fleischmann et al. [29] also found the positive linkage between environmental sustainability and reverse logistics operations.

The results show that competitive advantage has insignificant relationship with reverse logistics. On the other hand, financial and operational performance is improved by $11.5 \%$ and $12.1 \%$ respectively due to implementation of reverse logistics operations in pharmaceutical firms. Similarly Hazen et al. [30] found that operational performance of firms may be enhanced due to reduction of waste. Reverse logistics and green practices are most suitable for this purpose. Pagell et al. [31] and Acquaye et al. [32] highlighted that firms can improve their operational performance through adoption of successful reverse logistics implementation. On the other hand, Khan and Dong, [19] and Kaur et al. [33] conducted a research in the context of Pakistan and found that firms' financial performance can be enhanced by adoption of recycling, remanufacturing activities, which is a part of reverse logistic operations. In fact, they also emphasized that financial performance not only can be achieved through increment in profitability but also can be increased through reduction in end-to-end supply chain cost and the reverse logistics operations significantly reduce the cost of end-to-end supply chain [34-35].

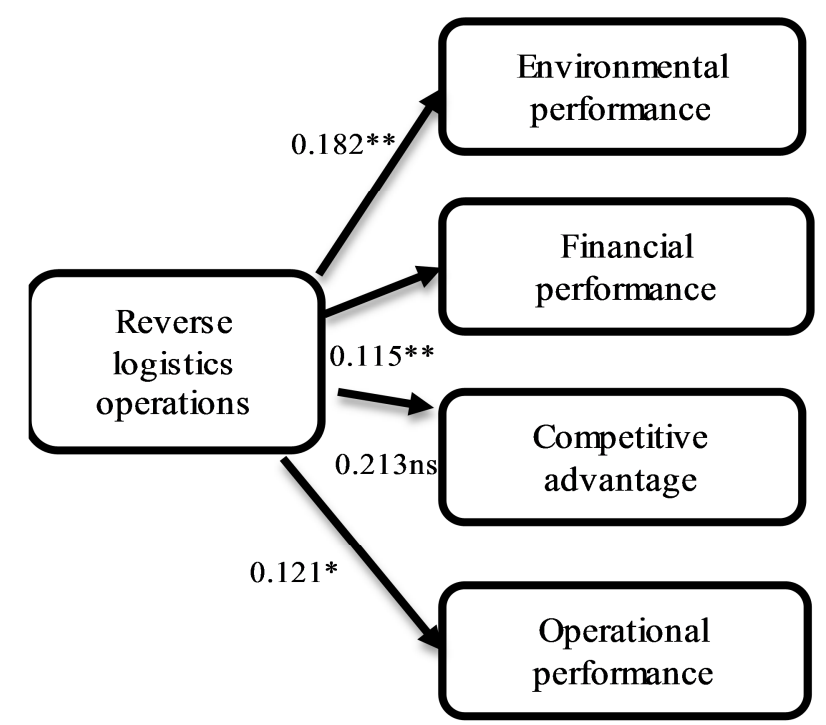

Figure 3. Model with Hypothesis Results.

\section{Conclusion}

The total hypothesis of research operational performance, financial performance and environmental performance are supported except competitive advantage. The figure 3 and table 3 have illustrated the results of hypothesis.

The study explores the effects of reverse logistics on environmental, financial and operational performance of pharmaceutical firms located in Mumbai, India. The results 
show firms performance would increase due to adoption of reverse logistics. In addition, a number of developed and developing countries have already adopted reverse logistics and reverse supply chain ideology in their firms, which enhance their performance on the whole. Therefore, it is suggested that the companies located in Mumbai, India should adopt reverse logistics in their firms to increase the overall performance including, environmental, operational, and financial performance.

\section{References}

[1] Green, K. W. Jr, McGaughey, R. and Casey, K. M. (2006), "Does supply chain management strategy mediate the association between market orientation and organizational performance?", Supply Chain Management: An International Journal, Vol. 11 No. 5, pp. 407-14.

[2] Tsoulfas GT, Pappis CP (2006) Environmental principles applicable to supply chains design

[3] and operation. J Clean Prod 14(18):1593-1602.

[4] Thierry M, Salomon M, Van Nunen J, Van Wassenhove L N (1995) Strategic issues in product recovery management. California Management Review 37, pp. 114-135.

[5] De Brito M P, Dekker R (2004) A framework for reverse logistics. In: Dekker R, Fleischmann M, Inderfurth K, Van Wassenhove L N (eds.) Reverse logistics: quantitative models for closed-loop supply chains, Springer-Verlag, Berlin, pp. $3-28$.

[6] Subramanian R, Subramanyam R (2012) Key factors in the market for remanufactured products. Manufacturing \& Service Operations Management 14, pp. 315-326.

[7] Agrawal V V, Atasu A, van Ittersum K (2012) Remanufacturing, third-party competition and consumers' perceived value of new products. Working Paper submitted to Management Science.

[8] Michaud C, Llerena D (2011) Green consumer behaviour: an experimental analysis of willingness to pay for remanufactured products. Business Strategy \& the Environment 20, pp. 408-420.

[9] Atasu A, Guide Jr V D R, Van Wassenhove L N (2010) So what if remanufacturing cannibalizes my new product sales? California Management Review 52, pp. 1-21.

[10] Stank, T. P., Davis, B. R. and Fugate, B. S. (2005), “A strategic framework for supply chain oriented logistics", Journal of Business Logistics, Vol. 26 No. 2, pp. 27-45.

[11] Council of Supply Chain Management Professionals (2007), "Supply chain management and logistics management definitions", available at: www.cscmp.org/Website/ AboutCSCMP/Definitions/Definitions.asp. de Kluyver, C. A. and Pearce, J. A. II (2006), Strategy: A View from the Top, 2nd ed., Pearson Prentice-Hall, Upper Saddle River, NJ.

[12] Rodrigues, A. M., Bowersox, D. J. and Calantone, R. J. (2005), "Estimation of global and national logistics expenditures: 2002 data update", Journal of Business Logistics, Vol. 26 No. 2, pp. $1-15$.
[13] Rabinovich, E. and Knemeyer, A. M. (2006), "Logistics service providers in Internet supply chains", California Management Review, Vol. 48 No. 4, pp. 84-108.

[14] Lai, K. and Cheng, T. C. E. (2003), "Supply chain performance in transport logistics: an assessment by service providers", International Journal of Logistics: Research and Applications, Vol. 6 No. 3, pp. 152-64.

[15] Chopra, S. and Meindl, P. (2004), Supply Chain Management: Strategy, Planning, and Operation, 2nd ed., Pearson Prentice-Hall, Upper Saddle River, NJ.

[16] Meredith, J. R. and Shafer, S. M. (2002), Operations Management for MBAs, 2nd ed., Wiley, New York, NY.

[17] Bowersox, D. J., Closs, D. J., Stank, T. P. and Keller, S. B. (2000), "How supply chain competency leads to business success", Supply Chain Management Review, Vol. 4 No. 4, pp. 70-8.

[18] Green, K. W. Jr and Inman, R. A. (2005), "Using a just-intime selling strategy to strengthen supply chain linkages", International Journal of Production Research, Vol. 43 No. 16, pp. 3437-53.

[19] Green, K. W. Jr, McGaughey, R. and Casey, K. M. (2006), "Does supply chain management strategy mediate the association between market orientation and organizational performance?", Supply Chain Management: An International Journal, Vol. 11 No. 5, pp. 407-14.

[20] Khan, S. A. R., \& Qianli, D. (2017a. Impact of green supply chain management practices on firms' performance: an empirical study from the perspective of Pakistan. Environmental Science and Pollution Research. https://doi.org/10.1007/s11356-017-9172-5

[21] Claycomb, C., Germain, R. and Dro"ge, C. (1999), "Total system JIT outcomes: inventory, organization and financial effects", International Journal of Physical Distribution and Logistics, Vol. 29 No. 10, pp. 612-30.

[22] Green, K. W. Jr, Medlin, B. and Whitten, D. (2004), "Developing optimism to improve performance: an approach for the manufacturing sector", Industrial Management \& Data Systems, Vol. 104 No. 2, pp. 106-14.

[23] Vokurka, R. J. and Lummus, R. R. (2000), "The role of just-intime in supply chain management", The International Journal of Logistics Management, Vol. 11 No. 1, pp. 89-98.

[24] Oliver, N. and Delbridge, R. (2002), "The characteristics of high performing supply chains", International Journal of Technology Management, Vol. 23 Nos 1-3, pp. 60-73.

[25] Carter, J. R. and Narasimhan, R. (1996), "Purchasing and supply management: future directions and trends", International Journal of Purchasing \& Materials Management, Vol. 32 No. 4, pp. 2-12.

[26] Wisner, J. D. (2003), "A structural equation model of supply chain management strategies and firm performance", Journal of Business Logistics, Vol. 24 No. 1, pp. 1-26.

[27] Armistead, C. G. and Mapes, J. (1993), "The impact of supply chain integration on operating performance", Logistics Information Management, Vol. 6 No. 4, pp. 9-14.

[28] Guide Jr V D R, Van Wassenhove L N (2009) The evolution of closed-loop supply chain research. Operations Research 57, pp. 10-18. 
[29] Stock J R (1992) Reverse logistics. Council of Logistics Management, Oak Brook, Illinois.

[30] Fleischmann M, Bloemhof-Ruwaard J M, Dekker R, van der Laan E, Van Nunen J, Van Wassenhove L N (1997) Quantitative models for reverse logistics: a review. European Journal of Operational Research 103, pp. 1-13.

[31] Hazen B T, Overstreet R E, Jones-Farmer L A, Field H S (2012) The role of ambiguity tolerance in consumer perception of remanufactured products. International Journal of Production Economics 135, pp. 781-790.

[32] Pagell M, Yang C, KrumwiedeDK, Sheu C (2004) Does the competitive environment influence the efficacy of investments in environmental management? J Supply Chain Management 40, pp. 30-39.

[33] Acquaye, A., Feng, K., Oppon, E., Salhi, S., Ibn-Mohammed, T., Genovese, A., \& Hubacek, K (2017) Measuring the environmental sustainability performance of global supply chains: A multi-regional input-output analysis for carbon, sulphur oxide and water footprints. Journal of environmental management, 187, pp. 571-585.

[34] Kaur, J., Sidhu, R., Awasthi, A., Chauhan, S., \& Goyal, S (2018) A DEMATEL based approach for investigating barriers in green supply chain management in Canadian manufacturing firms. International Journal of Production Research, 56 (1-2), pp. 312-332.

[35] Kovács, G (2017) The deadly life of logistics: mapping violence in global trade. Consumption markets and culture, 20(1), pp. 81-83.

[36] Laari, S., Töyli, J., Solakivi, T., \& Ojala, L (2016) Firm performance and customer-driven green supply chain management. Journal of Cleaner Production, 112, pp. 1960-1970. 